\title{
Value of cytoprognostic classification in breast carcinomas
}

\author{
JACQUELINE MOURIQUAND,* M GOZLAN-FIOR, * D VILLEMAIN, $\dagger$ \\ Y BOUCHET, JC SAGE,§ MA MERMET,* M BOLLAT
}

From the Divisions of *Cytology, $\ddagger$ Surgery, §Radiology, and $\llbracket$ Radiotherapy, and the $†$ Department of Pharmaceutical Mathematics and Physics, University Hospital of Grenoble, France

SUMMARY Two hundred and four cases of breast carcinoma were classified according to cytological features, and these were related to prognosis. A disease free interval of seven years was $95 \%$ for patients with grade I, $70 \%$ for those with grade II, and $45 \%$ for those with grade III tumours. The risk of recurrence was also related to tumour size and the presence or absence of steroid receptors in the tumour.

Cytological classification of breast carcinoma based on fine needle aspiration provides valuable information concerning the prognosis of patients, which is relevant to their clinical management.

During the past 10 years the importance of fine needle aspiration cytology in the diagnosis of breast lesions has been well documented. The combination of cytology, radiology, and clinical assessment results in an accurate diagnosis in $99 \%$ of cases. ${ }^{12}$ More recently, cytological features, seen in smears after fine needle aspiration or from imprints of tissue sections, have added valuable additional information about the prognosis of the disease. ${ }^{3-9}$

Fine needle aspirations or imprints of tissue sections ${ }^{10}$ are stained by a Papanicolaou hypochromic staining procedure. ${ }^{11} 12$ The pattern of distribution of chromatin, the differential staining affinity of nucleoli, the size of the nuclei, the tendency to clustering of cells, and other features lead to a "prognostic classification". 48913 In this study the prognostic value of such cytological features was applied to 204 cases of operable breast carcinoma collected from 1977 to 1980 . In addition, the oestrogen and progesterone receptor content of the tumour was available in all cases. The clinical course of the disease was correlated with cytoprognostic classification as well as with other recognised prognostic factors, such as the TNM classification, the histoprognostic classification of Scarff and Bloom, and the steroid receptor content of the tumour.

\section{Material and methods}

\section{PATIENTS}

Specimens of breast carcinoma were obtained from 204 women from 1977 to 1980 . All patients had been Accepted for publication 7 February 1985 submitted to the same radiosurgical management. In addition, chemoprophylactic treatment, such as that proposed by Carter, ${ }^{14}$ was given after radiotherapy to patients with unfavourable factors such as spread to the axillary nodes, absence of oestradiol receptor content in the tumour, and grade III cytoprognosis or histoprognosis. Bilateral and inflammatory carcinomas and tumours classified as stage IV by the TNM classification were excluded from the study as were patients with follow up times of less than $\mathbf{3 8}$ months.

Thus the occurrence of unfavourable events-local or controlateral recurrence, metastasis, or death-was recorded from 38 to 60 months after the first cytological diagnosis.

\section{CYTOLOGICAL SPECIMENS}

Cytological specimens were obtained by fine needle aspiration or from imprints of tissue sections at the

Table 1 Cytoprognostic classification: scoring system

\begin{tabular}{lll}
\hline & & Score \\
\hline \multirow{2}{*}{ Cells } & Isolated & 3 \\
& In clusters & 0 \\
& Large size & 3 \\
Nuclei & Anisokaryosis & 2 \\
& Naked & 3 \\
Enlarged & Budding & 2 \\
Nucleoli & Hypochromasia & 3 \\
Mitosis & Hyperchromasia & 2 \\
& Red & 3 \\
& Blue & 2 \\
\hline
\end{tabular}

Grade I: score <5

Grade II: score 5-9

Grade III: score $>10$ 


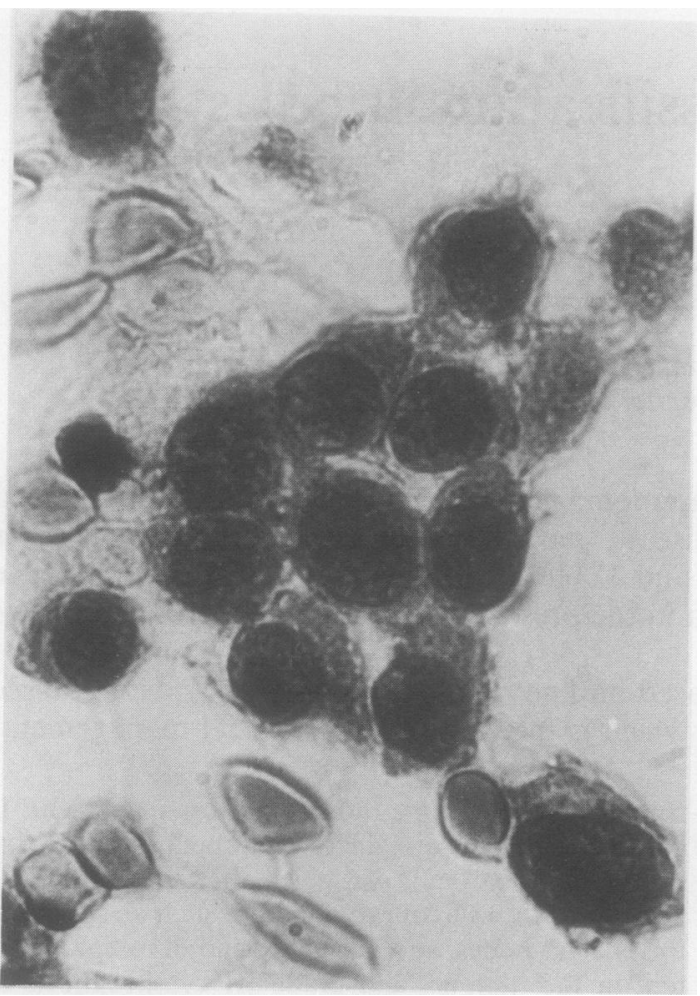

Fig. 1 Breast carcinoma grade 1 . Cluster of small malignant cells (score 0); round hyperchromic nuclei (score 2); no prominent nucleoli (score 0). Total score $=2$. Original magnification $\times 1250$.

time of surgery. They were fixed with an equal part of methanol-acetone, which permits immediate fixation and contributes to a relative hypochromy, and submitted to a hypochromic Papanicolaou staining procedure.

\section{Nuclear staining solution}

Harris alum haematoxylin was made as follows. Dissolve $1 \mathrm{~g}$ of haematoxylin in $10 \mathrm{ml}$ of absolute alcohol and $20 \mathrm{~g}$ of potassium alum in $200 \mathrm{ml}$ of distilled water by heating and mixing the two solutions together. Bring the mixture to a boil as rapidly as possible and then add $0.5 \mathrm{~g}$ of mercuric oxide. The solution immediately turns dark blue. Remove the vessel from the flame and cool by plunging it at once into a basin of cold water.

After haematoxylin staining (average time one minute) the slides are washed in running tap water and then destained in $\mathbf{0 . 5 \%}$ hydrochloric acid (five dips). Any further alkaline bath such as lithium carbonate solution or ammonium alcohol was avoided. (Other cytoplasmic counterstains 0G6 and EA 50 may be obtained commercially: EA 50 Merck is satisfactory).
CYTOPROGNOSTIC CLASSIFICATION

The smears were classified into three grades of $\underline{\vec{\sigma}}$ increasing severity. A simple numerical system was applied to both topographic and cytologic criteria $\stackrel{9}{?}$ (Table 1) (Figs. 1-4).

The arrangement of the cells on the smear reflected $\frac{\bar{C}}{\bar{F}}$ the degree of histological differentiation of the $\frac{\infty}{\vec{D}}$ tumour. In well differentiated carcinomas tubular $\stackrel{\mathbb{Q}}{\varrho}$ structures appeared as clusters in smears (score 0). A widespread distribution of isolated malignant cells $\overrightarrow{0}$ was typical of diffuse infiltration of breast tissue by anaplastic cells (score 3).

The cell size was taken into account: a well $\stackrel{\omega}{\circ}$ differentiated carcinoma has an average cell size of $\frac{7}{8}$ $12 \mu \mathrm{m}$ (score 0), and an anaplastic carcinoma has an average size of $21 \mu \mathrm{m}$ (score 3 ). This compares with an $\dot{ }$ ) average value of $9.9 \mu \mathrm{m}$ in normal breast cells.

As far as nuclei are concerned, they may be round (score 0 ), budding (score 2), or vary in size from cell 윽 to cell (score 2). When the hypochromic staining pro- cedure was applied to the smears the distribution of $\vec{z}$ chromatin was delicately outlined: in fast growing

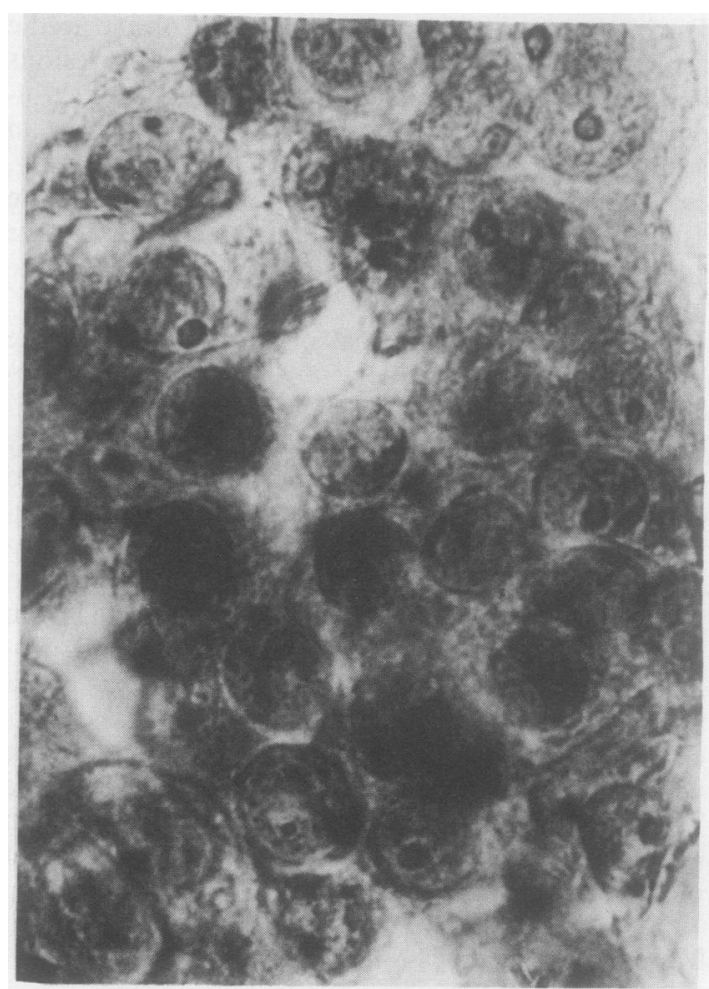

Fig. 2 Breast carcinoma grade II. Malignant cells isolated (not seen in the figure) (score 3) and in clusters.

Hypochromic (score 3) round regular nuclei (score 0).

Enlarged blue nucleoli (score 2). Total score $=8$. Original magnification $\times 1250$ 


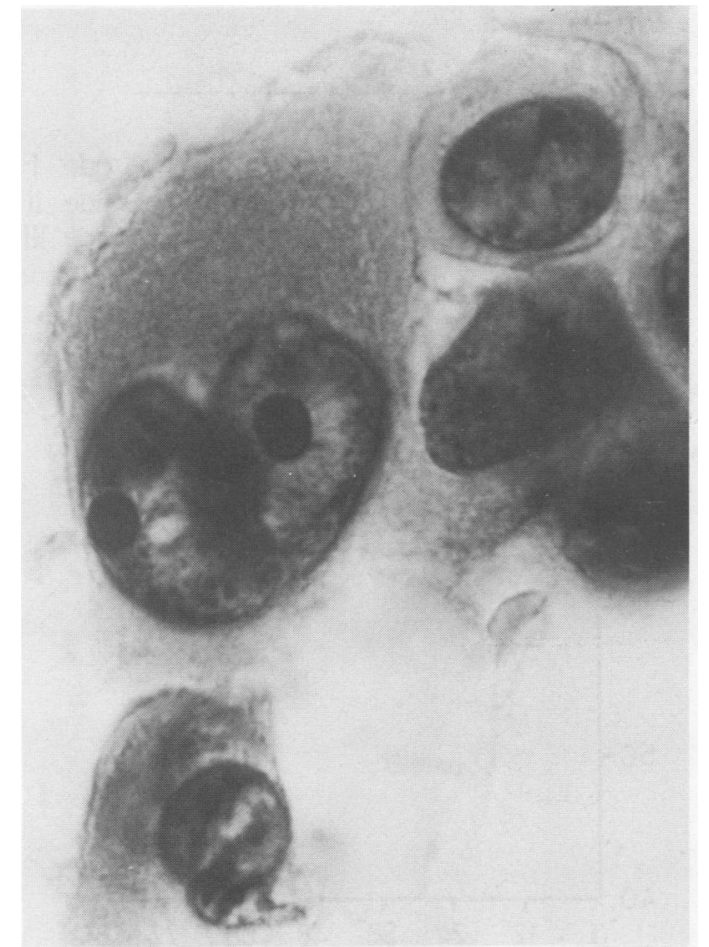

Fig. 3 Breast carcinoma grade III. Enlarged (score 3), isolated (score 3) malignant cells. Hypochromic intranuclear areas (score 3), anisokaryosis (score 2), budding nuclei (score 2). Total score $=13$. Original magnification $\times 1250$.

tumours diffuse or circumscribed areas of hypochromasia (score 3). Granular hyperchromic nuclei were scored 2 . Naked nuclei may be spread all over the smears in inflammatory carcinomas (score 3 ).

Differential staining affinity of nucleoli was seen, with enlarged red nucleoli, sometimes surrounded by a clear halo (score 3 ) in highly anaplastic cells or blue ones in more resting cells (score 2).

Evaluation of mitotic figures is important: more than three per slide score 1 and more than six per slide score 3.

The grade was obtained by adding the different scores obtained: grade 1 up to five, grade 2 from five to nine, grade 3 more than 10 .

A double malignant cell population was often found within the same tumour. For scoring purposes the most anaplastic cells were taken into account.

The prognostic importance of the secretory aspect of the cytoplasm and the presence of introcytoplasmic vacuoles, described by Spriggs ${ }^{15}$ require additional data, and are being mentioned merely as a reminder. assay: results were considered to be positive when they were above $10 \mathrm{fmols}$ per milligram of protein. ${ }^{16}$ Instructions were given to perform surgery during the first part of the menstrual cycle in premenopausal patients to avoid false negative progesterone receptor responses.

\section{STATISTICAL ANALYSIS}

Survival rates in complete remission were calculated on an actuarial basis. Statistical comparison of such curves of groups of patients was done by the Greenwood formula and $\chi^{2}$ test. The Mann-Whitney test was applied to small samples of patients. ${ }^{1718}$ Curves were plotted by the method of Kaplan and Meir. ${ }^{19}$

The incidence of unfavourable events per 1000 patients per month was obtained by multiplying the number of such events by 1000 and dividing the results by the number of months of follow up in complete remission.

\section{Results}

Table 2 shows the distribution of the patients in relation to their cytoprognostic classifications. The

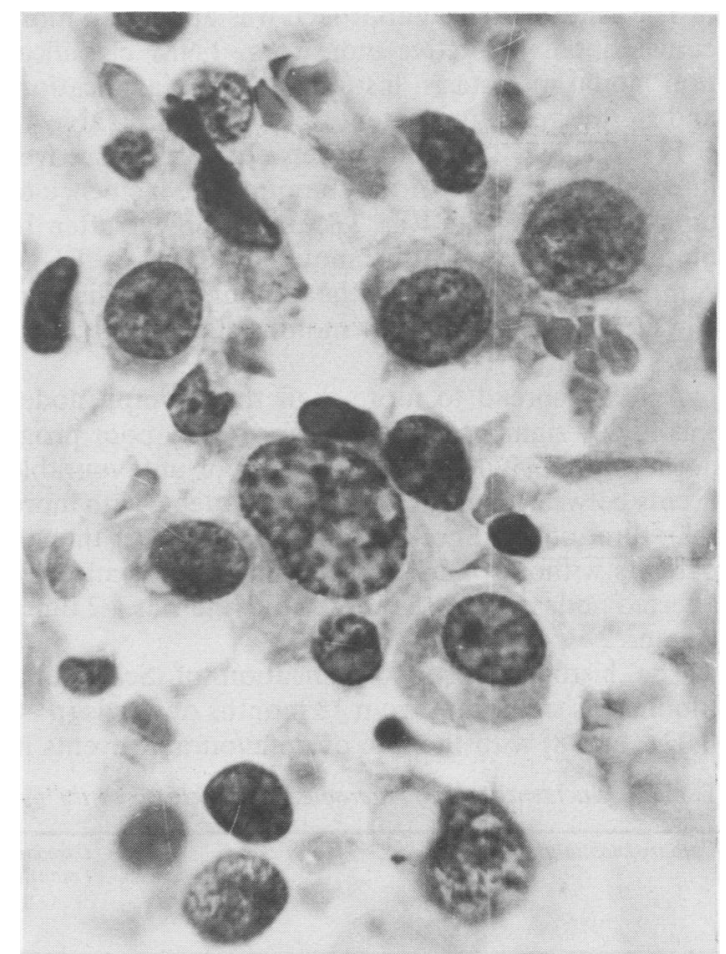

Fig. 4 Breast carcinoma grade III. Low magnification to show the widespread distribution of malignant cells, anisokaryosis, clear intranuclear areas, intracytoplasmic vacuoles. Original magnification $\times 500$. 
Table 2 Distribution of the 204 patients in relation to their cytoprognostic grades

\begin{tabular}{lcc}
\hline Cytoprognostic grade & No of patients & $\%$ \\
\hline I & 22 & 10.8 \\
II & 64 & 31.4 \\
III & 118 & 57.8 \\
Total & 204 & 100 \\
\hline
\end{tabular}

correlation between the disease free intervals of the 204 patients and their cytoprognostic classifications is given in Fig. 5. This does not take into account the other prognostic factors.

The incidence of unfavourable events per 1000 patients per month was significantly different for the three cytoprognostic grades (Table 3). Grade I, with 22 patients and only one unfavourable event, characterised a small group of patients $(10.8 \%)$ who had good prognoses. Statistical comparison of the occurrence of unfavourable events between grades II and III was highly significant $(p<0.01)$. The incidence of unfavourable events between 0 and 18 months was 3.6 times higher in grade III than in grade II. After 18 months the incidence in grade III was twice that in grade II.

The same statistical approach was applied to more conventional predictive indicators: TNM classification, nodal metastasis, histoprognostic classification, and steroid receptor content of the tumour (Table 4).

Fig. 6 shows the relation between the disease free interval and the size of the tumour. The incidence of unfavourable events was 2.85 times higher after 18 months in patients with tumours classified as T3-T4 compared with those with tumours classified as T1-T2; between 0 and 18 months it was only 1.92 times higher.

Axillary spread to more than three lymph nodes was highly significant as a factor of early poor prognosis ( $p<0.001$ ) (Fig. 7). The rate of unfavourable events between 0 and 18 months in patients with more than three affected nodes was 6.7 times higher than in patients without or in those having fewer than three affected nodes. After 18 months the rate was 4.2 times greater.

The histoprognostic classification of Scarff and Bloom was significant from 18 months onwards ( $p<$ 0.02 ) (Fig. 8) with the rate of unfavourable events in

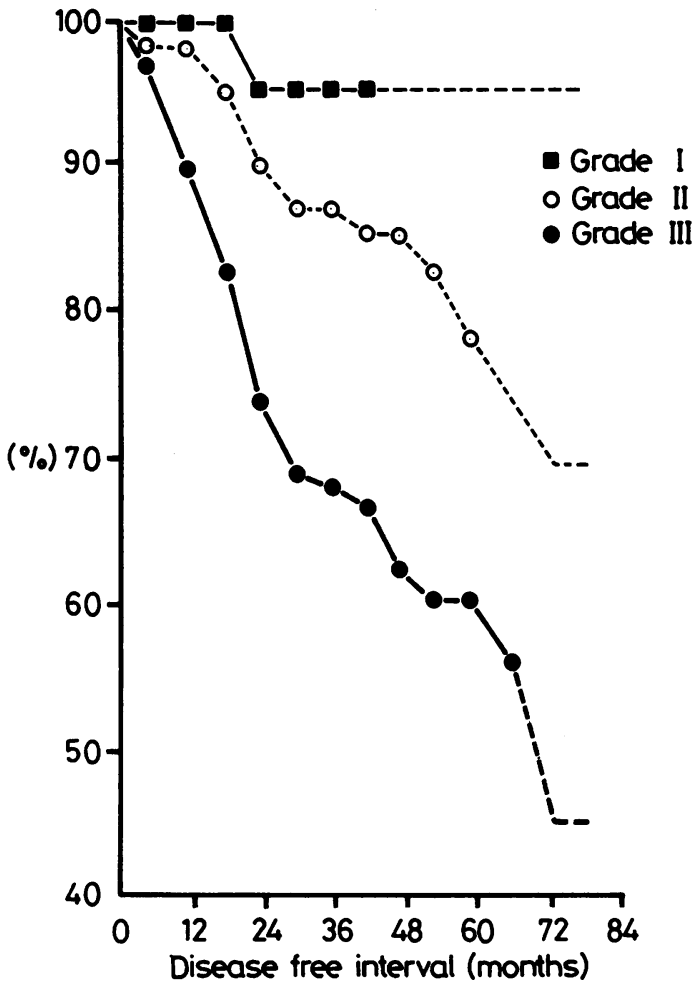

Fig. 5 Disease free interval correlated with cytoprognostic classification irrespective of all other prognostic factors.

grade III of the Scarff and Bloom classification $3 \cdot 1$ times greater than that of grade II. Thus this classification was a middle term marker.

The predictive value of the absence of progesterone and oestradiol receptors was also significant after 18 months ( $p<0.01$ ) (Fig. 9). The absence of oestradiol receptors alone was not significant $(p=9)$, while the absence of progesterone receptors alone was significant between 18 and 30 months $(p<0.01)$.

To summarise this sequential analysis of prognostic factors, grade III of the cytoprognostic classification and nodal metastasis equal to or greater than three or were the best predictive markers for a poor outcome $N$ in the short term (0 to 18 months). The size of the

Table 3 Incidence of unfavourable events related to the cytoprognostic grade

\begin{tabular}{|c|c|c|c|c|}
\hline \multirow[t]{2}{*}{ Cytoprognostic grade } & \multirow[t]{2}{*}{ No of cases } & \multirow{2}{*}{$\begin{array}{l}\text { Disease free interval } \\
\text { (months) }\end{array}$} & \multicolumn{2}{|c|}{ Unfavourable events } \\
\hline & & & Number & $\begin{array}{l}\text { Incidence } \\
\text { (1000 patients/month) }\end{array}$ \\
\hline $\begin{array}{l}\text { I } \\
\text { II } \\
\text { III }\end{array}$ & $\begin{array}{r}22 \\
62 \\
115\end{array}$ & $\begin{array}{r}988 \\
3083 \\
4754\end{array}$ & $\begin{array}{r}1 \\
12 \\
41\end{array}$ & $\begin{array}{l}1.01 \\
3.89 \\
8.62\end{array}$ \\
\hline
\end{tabular}

Unfavourable events = local or controlateral recurrence, metastasis, or death. 
Table 4 Distribution of unfavourable events within a short or middle term delay correlated with the different prognostic factors referred to in this study

\begin{tabular}{|c|c|c|c|}
\hline & & 0-18 months & 18-30 months \\
\hline $\begin{array}{l}\text { No of unfavourable events } \\
\text { Size of tumour }\end{array}$ & $\begin{array}{l}\text { T1-T2 } \\
\text { T3-T4 } \\
?\end{array}$ & $\begin{array}{l}23 \\
16 / 164 \\
6 / 32 \\
1 / 8\end{array}$ & $\begin{array}{l}22 \\
14 / 148 \\
7 / 26 \\
1 / 7\end{array}$ \\
\hline Scarff and Bloom classification & $\begin{array}{l}\text { I } \\
\text { II } \\
\text { III } \\
?\end{array}$ & $\begin{array}{l}0 / 31 \\
9 / 75 \\
6 / 48 \\
8 / 48\end{array}$ & $\begin{array}{r}1 / 31 \\
5 / 66 \\
10 / 42 \\
6 / 40\end{array}$ \\
\hline Axillary metastasis & $\begin{array}{l}n=0 \\
1 \leqslant n \leqslant 3 \\
1 \leqslant n>3 \\
?\end{array}$ & $\begin{array}{r}3 / 87 \\
4 / 54 \\
16 / 48 \\
0 / 15\end{array}$ & $\begin{array}{r}5 / 84 \\
5 / 50 \\
10 / 32 \\
2 / 15\end{array}$ \\
\hline Hormone receptor status & $\begin{array}{l}\text { ER-PR - } \\
\text { ER-PR+ } \\
\text { ER + PR - } \\
E R+P R+\end{array}$ & $\begin{array}{l}6 / 55 \\
2 / 22 \\
9 / 52 \\
6 / 75\end{array}$ & $\begin{array}{r}10 / 49 \\
2 / 20 \\
7 / 43 \\
3 / 69\end{array}$ \\
\hline Cytoprognosis & $\begin{array}{l}\text { I } \\
\text { II } \\
\text { III }\end{array}$ & $\begin{array}{c}0 / 22 \\
3 / 64 \\
20 / 118\end{array}$ & $\begin{array}{r}1 / 22 \\
5 / 61 \\
16 / 98\end{array}$ \\
\hline
\end{tabular}

ER $=$ oestrogen receptor.

PR = progestogen receptor.

tumour and histoprognostic classification were of middle term significance. The absence of progesterone receptors alone, or in association with oestrogen negative receptors, had a middle term predictive value (18 to 30 months).

Table 5 shows the correlation between the mean survival time after relapse of the disease and cytoprognostic classification. The difference between 10 months for patients classified as grade III and 23 months for patients classified as grade II was highly significant $(0.02>\mathrm{p}>0.01)$.

Grade I

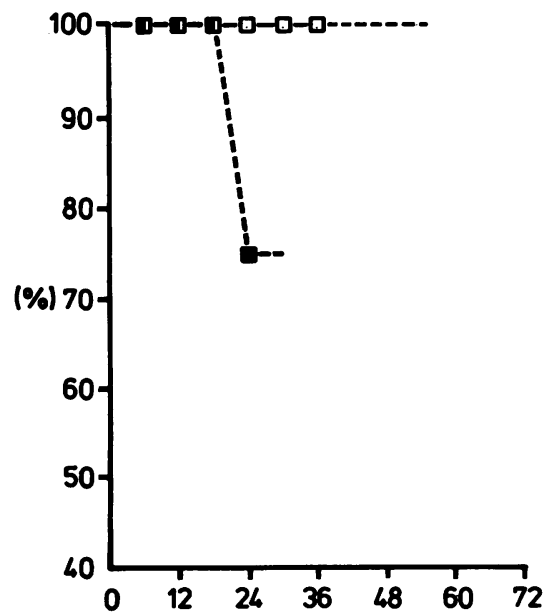

\section{Discussion}

Numerous investigators have tried to identify patients with the most aggressive breast tumours by means of histological grading systems, ${ }^{1320-24}$ and more recently, by investigating the prognostic value of hormone receptor content. ${ }^{1625-35}$

The cytoprognostic classification presented here rests partly on well established markers. It takes into account elements of the histological grading systems such as cell cohesion on the smear (isolated or in

Fig. 6 Curves of disease free interval correlated with size of tumour (TNM classification). Dotted lines are not significant. 
Fig. 7 Curves of disease free interval: interaction between cytoprognostic classification and nodal metastasis (N). Dotted lines are not significant.

clusters), which reflects the degree of differentiation of the tumour. Nuclear size is important in the Black histological classification and has been one of the main elements in several cytological classifications. ${ }^{36-38}$ The frequency of mitotic figures is evaluated in the different histological grading systems.
An increase in the size and number of nucleoli is a well known characteristic of cells engaged in growth and synthesis. This sign indicates poor prognosis in the present cytological classification, as well as nucleolar staining affinity, which, with the hypochromic Papanicolaou staining procedure, turns red in cells actively engaged in synthesis (pregnancy, lac-
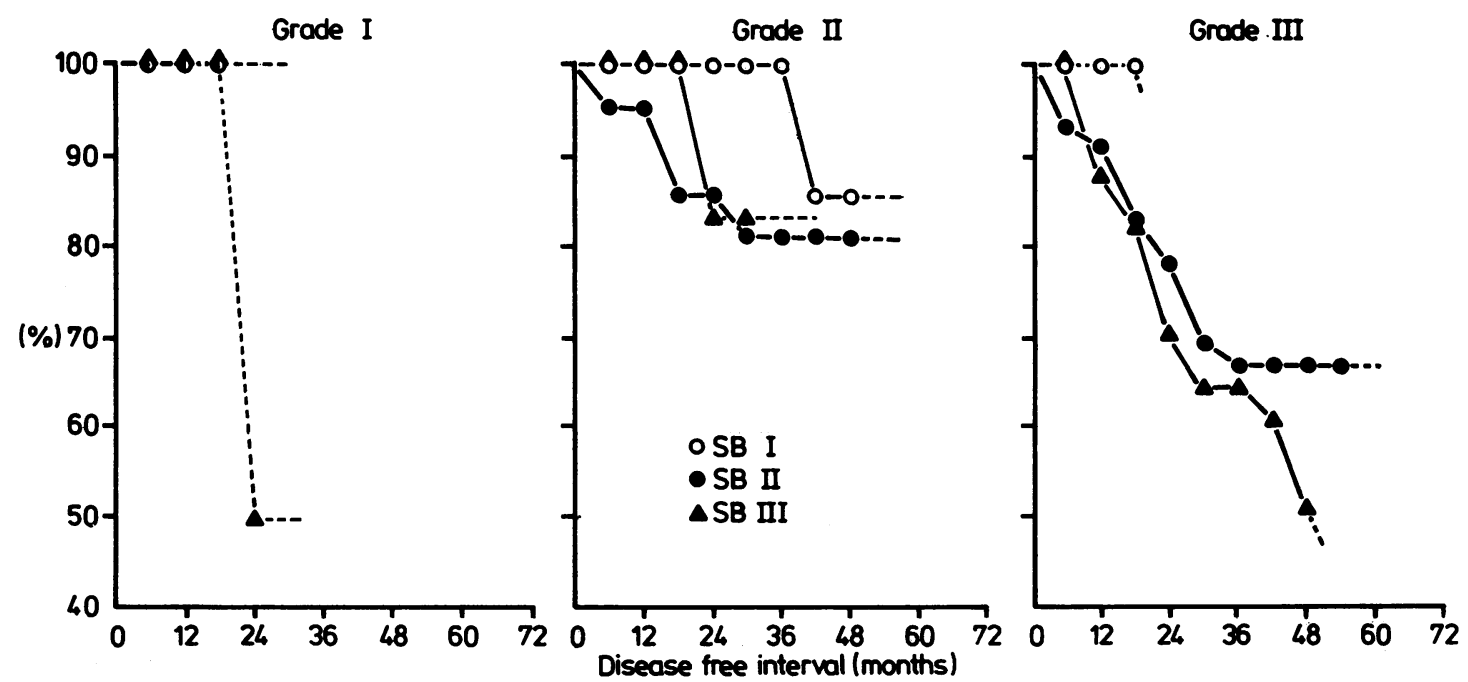

Fig. 8 Curves of disease free interval: correlation between cytoprognostic and histoprognostic (SB) classifications. Dotted lines are not significant. 
Table 5 Mean survival after recurrence of disease related to cytoprognostic classification

\begin{tabular}{ll}
\hline & Mean survival (mo) \\
\hline Grade II & $23 \pm 5$ \\
Grade III & $10 \pm 2$ \\
\hline
\end{tabular}

Student's $t$ test $=2.53$

$0.02>\mathrm{p}>0.01$

tation, and highly anaplastic malignant cells) ${ }^{3-9} 39$

The 60 month follow up enabled us to define the three well identified grades with significantly different prognoses. The information obtained from fine needle aspiration of the tumour was of value in the treatment of the patient. Grade I $(10 \cdot 8 \%)$ was indicative of good

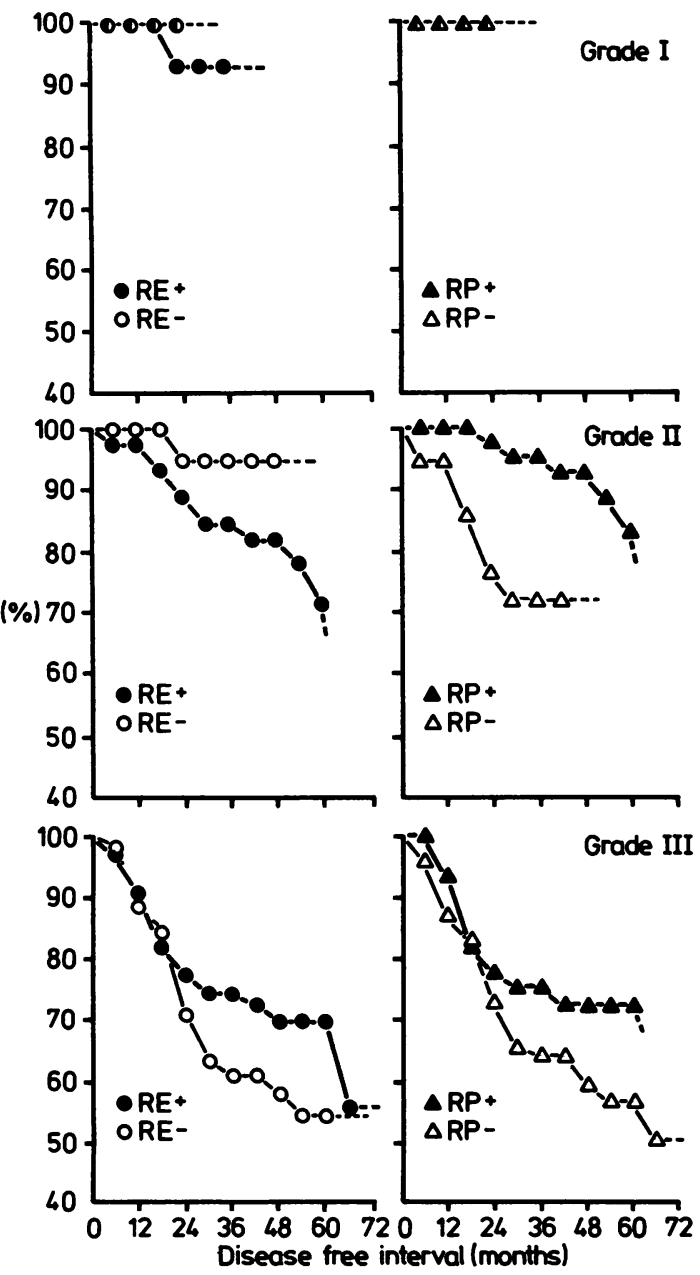

Fig. 9 Curves of disease free interval: correlation between cytoprognostic classification and presence of steroid receptors. $E R=$ oestrogen receptor; $P R=$ progesterone receptor. Dotted lines are statistically not significant. prognosis (only one unfavourable event). Grade II $(31.4 \%)$ seemed to be an intermediate prognostic category, with eight of 64 relapses of the disease within 30 months. Grade III indicated poor prognosis, with 36 out of 118 recurrences of the disease in the same time scale.

The risk of recurrence has been correlated with other well known prognostic factors. The time dependency of the predictive power of the variables has been shown before and after 18 months of follow up. Cytoprognostic classification grade III and the size of axillary metastasis $(n>3)$ predict a poor outcome before 18 months. After this time the size of the tumour (T3-T4 v T1-T2), histoprognostic grade III, and the absence of steroid receptors can predict the possibility of recurrence.

The results of the current study agree closely with those of Stenkvist $e t a l,{ }^{40}$ who found that the size of axillary metastasis and primary tumour, the number of lymphocytes around the tumour, the mitotic frequency, and the degree of differentiation have a strong predictive value during the first two and a half years. They did not take into account the steroid receptor content of the tumour, which seems to be correlated with the degree of differentiation of the tissue. ${ }^{21} 252631$

Although the predictive value of such receptors is still debatable, Stewart $e t$ al $^{35}$ in a recent study of 457 operable patients found no important differences in disease free interval between patients with oestrogen receptor positive and oestrogen receptor negative tumours or progesterone receptor positive and progesterone receptor negative tumours. Hilf et $a^{29}$ failed to show the usefulness of oestrogen receptor status as a predictor of the disease course or its response to treatment. Saaman $e a^{33}$ found that the disease free interval was appreciably longer in oestrogen receptor positive premenopausal patients than in those negative for oestrogen receptors, which was not the case in postmenopausal women. They found that the disease free interval was correlated with nodal disease irrespective of oestrogen receptor. The value of steroid receptors as predictors of response to hormone treatment reaches only $53 \%$ for oestrogen receptor positive and $75 \%$ for oestrogen and progresterone receptor positive tumours. ${ }^{34}$

The predictive value of morphometry has been well documented. ${ }^{72636-3740-42}$ Our study, based on a cytoprognostic classification, enabled us to indicate those patients who run a high risk of early relapse at the time of fine needle aspiration or of imprints from tissue. Such groups of patients may benefit from systemic treatment in addition to local treatment of their breast carcinomas.

We thank Mrs Jacrot for her assistance with the statistical analysis and Mrs Louis, Mrs Bossan, and Mrs 
Petitpas for their technical help.

This study was supported by grants from the Fondation pour la Recherche Médicale, the Ligue Nationale Française Contre le Cancer, the Comité Espoir and the Conseil Scientifique of the University.

\section{References}

${ }^{1}$ Van Bogaert L, Mazy G. Reliability of the cyto-radioclinical triplet in breast pathology diagnosis. Acta Cytol 1977;21:60-2.

${ }^{2}$ Verhaeghe M, Cornillot M, Herbeau J, Wintz A, Verhaeghe G. Le triplet diagnostic cyto-radioclinique dans les tumeurs due sein. A propos de 2460 cas. Mémoire Académie Chirugie 1969;95:48-61 .

${ }^{3}$ Mouriquand J, Vincent F, Vrousos C. Cytopronostic des cancers mammaires d'évolution aigüe et/ou défavorable. In: Colin C, Frunchimont P, eds. Functional explorations in senology. Ghent: European Press, 1976: 111-23.

${ }^{4}$ Wallgren A, Silfversward C, Zajicek J. Evaluation of needle aspirates and tissue sections as prognostic factors in a mammary carcinoma. Acta Cytol 1976;20:314-8.

${ }^{5}$ Wallgren A, Zajicek J. The prognostic value of the aspiration biopsy in mammary carcinoma. Acta Cytol 1976;20:479-85.

${ }^{6}$ Bolla M, Mouriquand J, Bouchet Y, Sage JC, Vrasos C. Interest of cytoprognosis classification in the management of breast carcinomas. In: Capesius B, ed. Proceedings of the XVth International Congress of Radiology. Brussels 1981. Luxembourg: Interimage Publications, 1983: 391-9.

${ }^{7}$ Mouriquand J, Bodin JP, Sage JC, Egal-Bourlard V, Peralta JL, Bouchet Y. Cyto-pronostic préthérapeutique du cancer du sein. 192 observations. Nouv Press Med 1979;8:2877-80.

${ }^{8}$ Mouriquand J, Pasquier D. Fine needle aspiration of breast carcinoma: a preliminary cytoprognostic study. Acta Cytol 1980;24:153-9.

${ }^{9}$ Roglic M, Mouriquand J. Classification cytopronostique des tumeurs du sein. Senologia 1980;5:151-4.

${ }^{10}$ Mouriquand J, Dargent M. L'empreinte mammaire. Etude cytopathologique. Bull Cancer (Paris) 1957;44:449-65.

${ }^{11}$ Mouriquand J. "Des" Colorations de Papanicolaou. Arch Anat Cytol Pathol 1979;27:328-30.

${ }^{12}$ Mouriquand J, Mouriquand C, Petitpas E, Louis J, Mermet MA. Differential nucleolar staining affinity with a modified Papanicolaou staining procedure. Stain Technology 1981;56:215-9.

${ }^{13}$ Fischer ER, Sass R, Fischer B. Pathologic findings from the national surgical adjuvant project for breast cancers. Cancer 1984;53:717-23.

${ }^{14}$ Carter SK. The design of clinical trials in cancer therapy. In: Staquet M, ed. Brussels: European Scientists, 1972.

${ }^{15}$ Spriggs AI, Jerrome DW. Intracellular mucus inclusions. J Clin Pathol 1975;28:929-36.

${ }^{16}$ Bolla M, Chedin M, Chambaz E, Gabelle Ph. Récepteurs à oestradiol et à progestérone dans le cancer du sein loco-régional. Corrélations cliniques et pronostiques. Sem Hôp Paris 1984;60:91-4.

${ }^{17}$ Schwartz D. Méthodes statistiques à l'usage des médecins et des biologistes. 3rd ed. Paris: Flammarion, 1969.

${ }^{18}$ Schwartz D, Flamand R, Lellouch J. L'essai thérapeutique chez l'homme. Paris: Flammarion, 1970.

${ }^{19}$ Kaplan EL, Meir P. Nonparametric estimation from incomplete observations. Journal of the American Statistical Association 1958;53:457-81.

${ }^{20}$ Bloom HJG, Richardson WW. Histological grading and prognosis in breast cancer. Br J Cancer 1957;11:359-77.
${ }^{21}$ Contesso G, Delarue JC, Mouriesse H, May-Levin F, Garnier H. Anatomopathologic du cancer du sein et récepteurs hormonaux. Path Biol 1983;31:747-54.

${ }^{22}$ Dawson PJ, Ferguson DJ, Karrison T. The pathologic findings of breast cancer in patients surviving 25 years after radical mastec- $\stackrel{\vec{\rho}}{\rightarrow}$ tomy. Cancer 1982;50:2131-8.

${ }^{23}$ Haagensen CD. Diseases of the breast. New York: WB Saunders, 1971.

${ }^{24}$ Henderson C, Canellos GP. Cancer of the breast. The past decade. $N$ Engl J Med 1980;302:17-30.

${ }^{25}$ Antoniades K, Spector $\mathrm{H}$. Correlation of estrogen receptor levels with histology and cytomorphology in human cancer. Am J Clin ô Pathol 1979;71:497-503.

${ }^{26}$ Cheix F, Biron A, Bailly C, Mayer M, Pommatau E, Saez S. Cancer du sein opérable: valeur pronostique des récepteurs d'estradiol. Nouv Presse Med 1980;9:933-5.

${ }^{27}$ Fior M. Grade cytopronostique des cancers du sein et récepteurs stéroïdiens. University of Grenoble, (Thesis.) Grenoble, 1984.

${ }^{28}$ Hannul R, Wooding T, Vivian AB. Prognostic value of estrogen $\omega$ receptors in primary breast cancer. Cancer 1978;44:671-5.

${ }^{29}$ Hilf R, Feldstein ML, Gibson SL, et al. The relative importance of iv estrogen receptor analysis as a prognostic factor for recurrence $\infty$ or response to chemotherapy in women with breast cancer. Cancer 1980;45:1993-2000.

${ }^{30}$ Knight WA, Livingston RB, Gregory EJ, Walder AI, McGuire WL. Estrogen receptor as an independent prognostic factor for early recurrence in breast cancer. Cancer Res 1977;37:4669-71. के

${ }^{31}$ Meyer JS, Ramanathe Rao B, Stevens SC, White WL. Low incidence of estrogen receptor in breast carcinomas with rapid rates of cellular replication. Cancer 1977;40:2290-8.

${ }^{32}$ Pichon MF, Pallud C, Brunet M, Milgrom E. Relationship of presence of progesterone receptors to prognostic in early breast cancer. Cancer Res 1980;40:3357-60.

${ }^{33}$ Saaman NA, Buzdar AU, Aldinger KA, et al. Estrogen receptor: a prognostic factor in breast cancer. Cancer 1981;47:554-60.

${ }^{34}$ Seibert K, Lippman M. Receptors in breast cancer. In: Baum M, ed. Clinics in oncology, New York: WB Saunders, 1982.

${ }^{35}$ Stewart JH, Rubens RD, Millis RR, King JB, Hayward JL. Steroid receptors and prognosis in operable (Stage I and II) breast cancer. Eur J Cancer Clin Oncol 1983;19:1381-7.

${ }^{36}$ Baak JPA, Kurver PHJ, De Shoo-Niewlaat, et al. Prognostic indications in breast cancer-morphometric methods. Histopathology 1982;6:327-39.

${ }^{37}$ Kuenen Boomester V, Hop WCJ, Blonk DI, Boon M. Prognostic scoring using cytomorphometry and lymph node status of ? patients with breast carcinoma. Eur J Cancer Clin Oncol 1984;20:337-45.

${ }^{38}$ Haybittle JL, Blamey RW, Elston CW, et al. A prognostic index in primary breast cancer. Br J Cancer 1982;45:361-6.

${ }^{39}$ Stenkvist B, Bengtsson E, Danlqvist B, et al. Predicting breast cancer recurrence. Cancer 1982;50:2884-93.

${ }^{40}$ Castelain G. Cytodiagnostic extemporané et cytopronostic des tumeurs du sein. Pathol Biol (Paris) 1958;3:235-9.

${ }^{41}$ Mossler JA, McCarty KS, Woodard BH, Mitchener LM, Johnston WW. Correlation of mean nuclear area with estrogen receptor $N$ content in aspiration cytology of breast carcinoma. Acta Cytol $1982 ; 4: 417-21$.

${ }^{42}$ Schenk U, Burger G, Jutting U, Peters-Welte C, Eiermann W. N Punktionszytologie der Mamma. Korrelation visueller und bild analytischer Intersuchungen mit dem Hormonrezeptorstatus. Geburtsh u Frauenheik 1985;45:17-21.

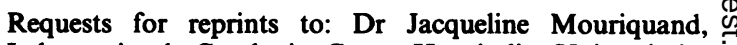
Laboratoire de Cytologie, Centre Hospitalier Universitaire de Grenoble, BP 217 X - 38043 Grenoble Cedex, France. 